\title{
Chronic cutaneous lupus erythematosus and topical clindamycin
}

\author{
Andrew J Newman, ${ }^{1}$ Andrea Schneider, ${ }^{2}$ Brooke Blumetti, ${ }^{1}$ Jason Barr ${ }^{1}$
}

'Dermatology Residency, Affiliated Dermatology, Scottsdale, Arizona, USA ${ }^{2}$ College of Osteopathic Medicine, Midwestern University, Glendale, Arizona USA

\section{Correspondence to} Dr Andrew J Newman, anewman@affderm.com

Accepted 5 September 2018

\section{DESCRIPTION}

A 64-year-old Caucasian woman was seen in our office for several years for management of her chronic cutaneous lupus erythematosus (CCLE). Her condition consisted of violaceous papules and plaques with some focal atrophy distributed over the upper arms, face and scalp. Histopathology from two $4 \mathrm{~mm}$ punch biopsies performed on separate occasions demonstrated features on H\&E stain consistent with CCLE: epidermal atrophy and interface dermatitis with superficial perivascular, deep dermal and periadnexal lymphohistiocytic infiltrates containing some plasma cells. Her rash had frustrated her for over 5 years, worsening with increased sun exposure. Her collagen vascular serologies were negative. She had been managed with potent topical corticosteroids with improvement, however, the patient preferred to reserve this for flares of her condition. Interestingly, the patient had correlated dramatic clearing of her CCLE inadvertently after 3 months of applying topical clindamycin gel 1\% twice daily (figures 1 and 2), which was initially prescribed to her for mild comedonal acne. Her improvement maintained and her skin clearance was still appreciated at her follow-up visit over 6 months after having initiated the topical clindamycin. During this course, the patient denied having less sun exposure, and she denied using her previously prescribed topical corticosteroids.

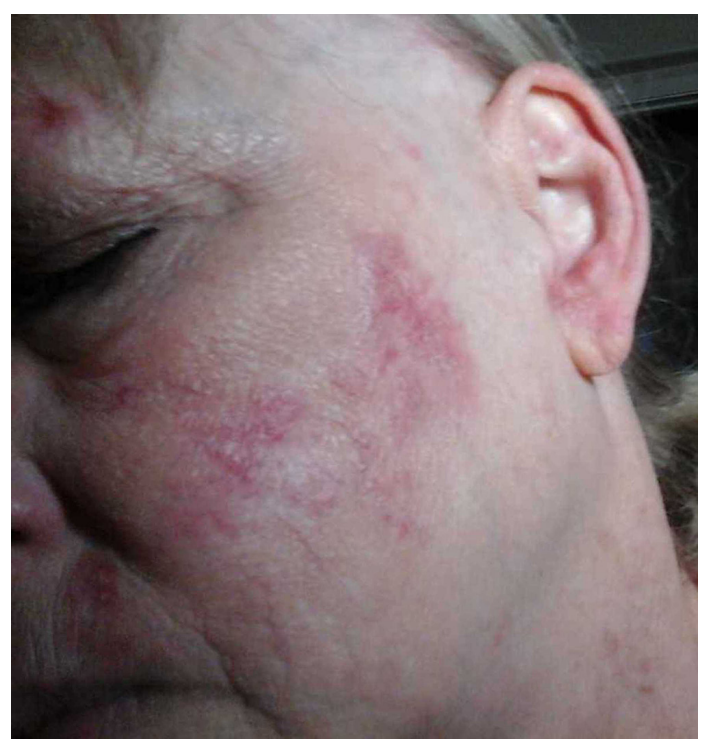

Figure 1 Chronic cutaneous lupus erythematosus of the face prior to treatment of topical clindamycin $1 \%$.

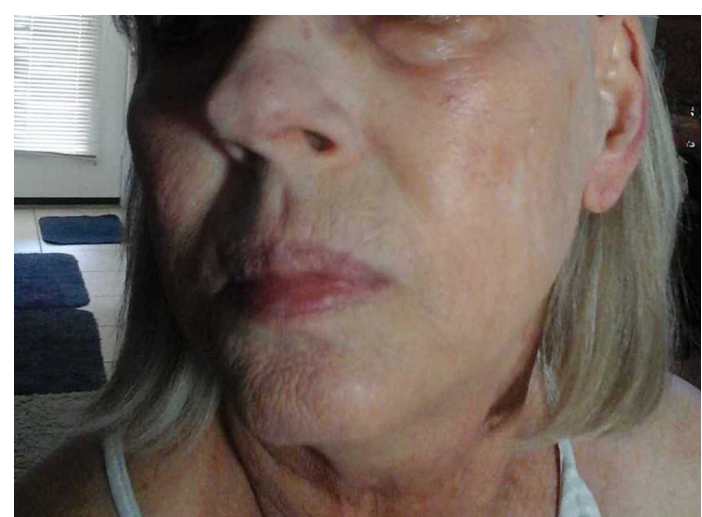

Figure 2 Chronic cutaneous lupus erythematosus of the face after 3 months of topical clindamycin $1 \%$.

An intriguing correlation between the use of topical clindamycin and the improvement of CCLE was observed. A possible contributor to this clearance may have been a change in the patient's exposure to sunlight. However, the authors of this manuscript feel that changes in the patient's sun exposure could not independently explain the marked skin clearing. First, the seasonal variation (and total radiant ultraviolet light variation) in the desert climate of the Phoenix Valley of Arizona is relatively low. Second, although the patient noticed the improvement during the fall, her skin clearance continued into the following spring and summer (she denied having any changes to her sun-avoidance behaviour). The authors of this manuscript were initially reluctant to think that a topical antibiotic could treat inflammatory dermatoses like CCLE-especially given this condition's involvement of the superficial and deeper dermis - yet they entertain that topical clindamycin imparted anti-inflammatory properties which improved this patient's CCLE. Clindamycin has been used in many skin conditions including acne, and it believed to work both as an antibiotic and anti-inflammatory. ${ }^{1}$ The next step to explore the utility of topical clindamycin in the treatment of CCLE would be to have this patient take at least

\section{Learning points}

- Clindamycin has been demonstrated to have anti-inflammatory properties and utility in the treatment of non-infectious skin conditions.

- A patient with chronic cutaneous lupus erythematosus was observed to have clear skin after 3 months of initiating topical clindamycin. 


\section{Images in...}

a 2-month holiday from the topical clindamycin followed by a reintroduction of the medicine to see if her disease would accordingly relapse then remit.

Acknowledgements We thank the devoted faculty and staff of Honor Health and Affiliated Dermatology of Scottsdale, Arizona for their support and encouragement.

Contributors AS: contributed text in the document, as well as performed a literature review needed for the background of this case. AJN: provided text to the case report. BB: edited the document. JB: was an invaluable medical consult to maintain the accuracy of the medical content.
Funding The authors have not declared a specific grant for this research from any funding agency in the public, commercial or not-for-profit sectors.

Competing interests None declared.

Patient consent Obtained.

Provenance and peer review Not commissioned; externally peer reviewed.

REFERENCE

1 Del Rosso JQ, Schmidt NF. A review of the anti-inflammatory properties of clindamycin in the treatment of acne vulgaris. Cutis 2010;85:15-24.

Copyright 2018 BMJ Publishing Group. All rights reserved. For permission to reuse any of this content visit

http://group.bmj.com/group/rights-licensing/permissions.

BMJ Case Report Fellows may re-use this article for personal use and teaching without any further permission.

Become a Fellow of BMJ Case Reports today and you can:

Submit as many cases as you like

- Enjoy fast sympathetic peer review and rapid publication of accepted articles

Access all the published articles

Re-use any of the published material for personal use and teaching without further permission

For information on Institutional Fellowships contact consortiasales@bmjgroup.com

Visit casereports.bmj.com for more articles like this and to become a Fellow 